\title{
Highly Skilled Professionals on the Move: The International Migration of South African Indians
}

DOI: $10.11567 /$ met.30.2.5

UDK: 316.344.32-057.56(684=214)"2006/2014"

314.743-057.4(684=214)"2006/2014"

Pregledni rad

Primljeno: 29.8.2014.

Prihvaćeno: 28.10.2014.

\section{Gerelene Jagganath}

Department of Anthropology, University of Kwazulu-Natal, Durban

gerelenej@gmail.com

\section{SUMMARY}

This paper is about the migration behaviour of highly skilled South African Indians from the period 2006 to present. The ethnography of the highly skilled is relatively new in Anthropology and while it contributes to recent discourse on migration and diaspora, it also foregrounds the need for an array of methodological approaches to support the global mobilities of people, the nature of multi-sited research and what "highly skilled" means in different geographical contexts. The paper is arranged in two parts: the first part contextualises the highly skilled professional in recent global migration literature and theory, and the second part presents case studies of highly skilled migrants in several international destinations, highlighting and contextualising their experiences abroad.

KEY WORDS: highly skilled, brain drain, brain gain, transnational migration, South African Indians

\section{INTRODUCTION}

Global market forces have set in motion migration patterns among highly skilled migrants in both the developed and developing world. To appreciate and foreground the migration trajectories of highly skilled South African Indian professionals, these trends must be viewed against the larger landscape of the great scale and reach of contemporary migration and its far-reaching impacts in South Africa. To begin with, the term "highly skilled" varies across geographical contexts but points to some similarity in the set of characteristics defining this category of migrant. The term "skilled personnel" has in earlier literature been used interchangeably with "highly skilled", which Gould (1988) refers to as the occupational categories of high 
level and general managers; scientists, engineers and those with professional technical skills; professionals in education, health and welfare; professionals in administration; professionals in literature, arts and sport; and, computer and Information Technology specialists. The definition of "highly skilled" depends on both an educational component and a threshold defining minimum competence in a knowledge-based society. Iredale (2001: 8) for instance, defines highly skilled migrants as "having a university degree or extensive/equivalent experience in a given field". Lowell (2008: 52) states that the most basic definition of highly skilled migrants tends to be restricted to persons with tertiary education, typically adults who have completed a formal two-year college education or more. This is also the most readily available international definition and by default, the most widely studied measure of highly skilled mobility. When possible, additional information regarding an academic or professional degree would be desirable. The author adds that the National Science Foundation of the United States, which has some of the most complete international data on the stock of scientists and engineers, tends to focus on data for holders of doctoral degrees. Most frequently, governments define highly skilled migrants not in terms of either/or, but in terms of both education and occupation. Spadavecchia (2013: 98) uses the definition of the highly skilled as proposed by the Council of the European Union (2009) in the Council Directive on European Blue Card as those people with a first-degree or higher education diploma of at least 3 years, or 5 years professional experience. Nathan (2014: 1) elaborates that "highly skilled migrants" are usually defined in terms of formal qualifications (education to degree level or beyond). In other cases the focus is on occupations requiring advanced training (scientists, engineers, researchers and other professionals). Alternatively, human capital is defined in terms of attitudes and soft skills (entrepreneurial drive and aptitude) as well as qualifications. A 2013 report by the South African investment company Adcorp Holdings Ltd, defines high skilled positions as people earning more than 400,000 rands $(\$ 36,786)$ per year $(\mathrm{Kew}, 2014)$. For the purposes of this paper, the author uses an understanding of highly skilled that encompasses a combination of tertiary education qualification/s, occupation and entrepreneurial skills.

The paper comprises two parts. The first part presents a brief overview of key theoretical concepts and frameworks such as brain drain, brain gain and transnational migration in the sub-Saharan and specifically South African context as well as the research methodology. The three theories provide much of the foundation upon which South African migration literature 
and discourse in the social sciences is predicated, although other theoretical frameworks (brain circulation, return migration, cosmopolitan, and development perspectives) also have their place in local migration debate. The second part provides case studies of professional Indian migrants in several international destinations.

\section{AN OVERVIEW OF THEORETICAL FRAMEWORKS OF MIGRATION AND THE HIGHLY SKILLED - SUB-SAHARAN AFRICA WITH AN EMPHASIS ON SOUTH AFRICA}

In 2010 there were 21.8 million international migrants from Sub-Saharan Africa (SSA) comprising 2.5\% of the region's total population (Migration and Remittances Factbook, 2011: 33). Contrary to international public perception, $63 \%$ of African migrants remained predominantly in Africa, while $24.8 \%$ migrated to the high-income Organization for Economic Cooperation and Development (OECD) countries. Preferred African destinations included South Africa heading the list, while leading overseas destinations included France, Saudi Arabia, United Kingdom (UK) and the United States of America (USA) with Italy and Spain more recently (Spadavecchia, 2013). This is not the case for South Africa, where most migrants leave for overseas destinations. The traditional five emigration destinations which host $90 \%$ of highly skilled South Africans include the UK, Australia, New Zealand, Canada, USA and more recently, the United Arab Emirates (UAE) (Nyamvura, 2014). In economic and fiscal terms, highly educated workers generate positive externalities to national economic growth and development. Considered as assets to a country's resources these externalities include: productivity spillovers to both high and low skilled workers; immediate and future social spillovers to both education and healthcare services; innovative and creative potential for long-term national growth; and contributions to the well-being of a country's social, political and economic institutions. Moreover, given that tertiary education is publically financed and that the highly educated are net fiscal contributors on entering the labour market, their migration implies a national fiscal loss (Ratha et al., 2011: 111). Some of the noted benefits, however, include remittances; the creation of social and economic linkages between the home country and host country; an increase in overall human capital accumulation; and the return of professionals with enhanced skills and specializations. It is argued that there are far more benefits than disadvantages in the migration of highly skilled persons particularly if the country of origin does not have the necessary resources 
(poor investment climate, inadequate facilities or an ailing economy) for professionals to fully utilize their skills (Migration and Remittances Factbook, 2011: 111). Measuring the actual costs and benefits of the migration of the highly skilled proves tenuous as most theoretical positions seldom show a connection with the experience of the migration trajectory which includes both the migrant and those who are left behind.

The brain drain, brain gain and transnational theoretical frameworks dominate international migration research in South Africa. Brain drain and brain gain perspectives provided the original impetus from which more sophisticated and nuanced perspectives such as transnational migration theory followed.

\section{Brain drain}

The United Nations define the now well-established concept "brain drain" as a one-way movement of highly skilled people from developing countries to developed countries that exclusively benefits the industrialised (host) world (Oberoi and Lin, 2006). It could therefore be described as the depletion or loss of intellectual and technical human capacity by the source country. Another major disadvantage to source countries with regard to medical graduates is the term "free riding" - the substantial financial savings in training and education by the host/recipient countries when they obtain highly qualified individuals who migrate to seek employment outside their countries of origin. It costs a government in the developing world approximately US $\$ 100,000$ or more to train a medical student. It has been estimated that the total monetary loss by developing countries due to losing healthcare workers they have trained equals US\$500 million annually (Bezuidenhout et al., 2009: 212). The loss of skilled workers, especially for the poorest countries in Africa and in critical sectors such as health and education, imposes enormous costs on those countries. A report by the International Labour Organization (ILO) The Decent Work Agenda in Africa: 2007 - 2015 (2007) highlights the fact that while the number of highly skilled workers are more likely to emigrate to the OECD countries, Africa in general is not well represented among immigrants in the OECD. If we define the brain drain as the proportion of a country's university-educated nationals living in the OECD, 21 of the 40 countries with the most acute brain drain problems are African. However, in relation to world emigration flows (and the total number of emigrants to the OECD), $50 \%$ of the immigrants in the OECD are from other OECD countries (African Economic Outlook, 2011). It is the low levels of skilled human capital in African countries that amplify 
the effects of high-skilled migration. South Africa alone accounted for $60 \%$ of the stock total of migrant physicians in 2004 (Docquier and Marfouk, 2007). Many of the countries with high physician emigration rates also have high nurse emigration rates, suggesting that the same factors (low income, lack of professional development prospects, insufficient postgraduate training opportunities, poor facilities/equipment/medical supplies and support staff) influence migration decisions (Migration and Remittances Factbook, 2011). The negative impacts of the migration of local doctors, nurses and healthcare practitioners is well documented and the ailing national health care crises with staff shortages is foregrounded in both the media and local studies (see Mills et al., 2011; Beine, Docquier and Rapoport, 2008).

\section{Brain gain}

Brain gain claims that the migration of highly skilled professionals generates benefits for the home country when migrants send remittances to immediate and extended families; creates economic and social linkages between countries; and generates positive diaspora influences with the return of better skilled professionals. In a press release (12 May 2014), a South African Institute for Professional Accountants (SAIPA) economic research analyst maintained that if South Africa unleashed the huge potential of skilled immigration, it could not only balance the brain drain but even realize a brain gain and tap into a major driver of growth and job creation (Naymura, 2014). Naymura (2014) stated that while both developed and developing economies are losing their own skilled populations, South Africa could harness the international mobility of highly skilled people in two ways: namely, by actively attracting foreign skills, while also tapping into the potential that its own expatriate population offers. It seems that the obvious solution to the limited local supply of skills would be to source skills from abroad which could assist South Africa in the achievement of its economic and developmental objectives. He further commented that the highly skilled population holds the potential to be harnessed beyond the obvious benefits of remittances. This would include those expatriates willing to maintain ties with South Africa who could make contributions in the form of technology and knowledge transfer, co-operation between institutions, the creation of business and trade networks, trade creation, the channelling of resources and directing foreign investment back to South Africa. Migration and development optimists promote international migration as a "win-win situation" for all by promoting the idea that diasporas are not a loss but a benefit and potential gain (Plaza and Ratha, 2011). 


\section{Transnational migration theory}

The transnational migration perspective considers the transnational dimension of social life for both migrant and non-migrant populations. The spatial mobility, sophisticated communication via the internet and geographically protracted social relations, shaping the transnational lifestyle has led to the concept of transnational social fields. Levitt and Glick Schiller (2004) refer to these social forms that span borders and connect interlinked territories and social spaces with overlapping power hierarchies. The transnational social field has become a means by which to examine new forms of social identities, positions and power relations between people, places, traditions and institutions. It also provides a multifocal analytical framework that brings meaning to migrants' behaviours in the transformation of their social roles and status (Nedelcu, 2012: 7). Beck (2008) succinctly surmises how families living transnationally, second-generation children speaking two or more languages from an early age, transnationally educated mobile professionals who acquire eclectic social and cultural skills and non-migrants learning a sense of otherness at "home" - are shaping the ontological symbols of a cosmopolitanisation process through which people become aware of the relativity of their social position and culture within a larger global social space. The life trajectory of migrant professionals is built within a culture of mobility, both professional and geographic. Information and Communication Technologies (ICT's) have helped transform migrant professionals' understanding of time-space limitations and have facilitated transnational mindsets and meanings within the societies they encounter. Transnational migration theory thus offers a far more nuanced perspective of the interaction between globalisation and the social worlds of the highly skilled migrant.

The influence and impact of the basic tenets of brain drain, brain gain and transnational migration theories are relevant for the African and specifically South African contexts. Importantly, the increase in autonomous female migration is evident among professional women in general (both single and married) who are engaging in international migration. A significant proportion of such women are educated, as well as highly skilled migrants who move independently to fulfil personal as well as household economic needs and are no longer simply "trailing wives" or part of a family reunification process. The gendered nature of migrant experience has only recently found a foothold in South African migration studies. Transnational migration theory embraces specific gendered experiences and the 
roles of women in the creation of social fields and spaces such as transnational families, transnational parenting and transnational care. Migration research concerning South African Indian women is scarce but increasingly significant in this context (see Pattundeen, 2007; Govender and Sookrajh, 2013) and a glimpse into their distinctive migration experiences is provided later on.

\section{RESEARCH METHODOLOGY}

This paper is based on a reflection of three sources of qualitative research data collected: between 2006 - 2008 among a selected sample of 25 highly skilled professional Indian women working in the UK; in 2010 from the responses of an e-questionnaire administered to 15 highly skilled Indian male migrants working in Dubai; and in 2014 from an e-survey to which 5 highly skilled Indian males and 5 female migrants residing in OECD countries responded. The ages of the participants of the three samples ranged from 25 to 65 years and their professional status included: health care practitioners (speech and hearing therapists, optometrists, dentists and nurses), medical doctors, engineers, accountants and executive management personnel. Overall, the sample consisted of 30 female and 20 male migrant informants.

Most of the women in the sample were interviewed on their return visits to South Africa (the only option of accessing face-to-face interviews in the research) but the males in the sample were almost entirely accessed via referrals from the sample and other social networks while residing overseas. Their responses proved the most problematic due to a lack of detail and an inability to timeously verify data through email communication. However, the data provided sufficient signifiers on certain issues relating to migration choices and destination trends. Hence the data collected represents the general trends of highly skilled male migrants and the more specific gendered experiences of highly skilled female migrants for this ethnic enclave. Common threads in motivations and perceptions were noted as well as newly emerging migration trajectories, indicating dynamic and changeable migration processes and migration experiences in the period from 2006 to the present. The case studies of the six migrants to be presented in the paper serve to highlight these trends as well as challenge conventional ideas regarding highly skilled professionals from South Africa. Media coverage (news articles, press releases and media reports) referred to, substantiates local scholarly discourse on migration. The various modes of data collection were inevitable given the mobility of the sample. Primary data was 
obtained from interviews, e-questionnaires and the e-surveys while content analysis of media reports supplemented the data presented in this paper.

The Indian population in South Africa constitutes approximately 1.2\% of the total population and contemporary local migration studies subsumes their migration experiences and statistics under the category of "black" South African, or it is assumed under the general category of South African professionals (Pattundeen, 2007). The blanket categorization of the term "black" presents a superficial index and obscures the complexities of the migration process for Indians and Coloureds (of mixed racial descent) (see Waller, 2006; Crush, Pendelton and Tevera, 2005). Academic research on the migration of professionals in the past decade by Pattundeen (2007), Singh (2008) and Manik (2010), provide some of the few academic resources on which contemporary migration of South African Indians is examined. The migration of South African professionals since 2006 has seen a rise in the numbers of highly skilled Indian, Coloured and Black (of African descent) ethnic groups indicating a shift from the apartheid era when it was predominantly White (of European descent) South Africans who left the country in what was referred to as the "white flight". In post-apartheid South Africa, one of the defining migration motivations among White and Indian migrants has been the implementation of an Affirmative Action Policy which the informants cite as one of the key reasons for leaving the country.

The section below presents case studies which contextualise the migration experiences, highlighting the similarities and variations in the motivations, destination choices and remittance behaviour of the sample.

\section{FINDINGS AND DISCUSSION}

\section{One size does not fit all: mobility and remittance behaviour of highly skilled South African Indian migrants}

This section of the paper provides a window into the lives of a few highly skilled migrants whose profiles are meant to show their mobility and remittance behaviour while also examining the degree to which their South African-ness and Indian-ness emerge in the global context. The six profiles selected represent a cross-section of informants across three important historical migration junctures (post-apartheid South Africa, post-world economic crisis of 2008 and the present, twenty years after South Africa became a democracy). Neeta and Kajal are part of the professional female sample (2006 - 2008) which represent the more traditional highly skilled destinations; Cassim's story is from the e-questionnaire sample in Dubai (2010) and 
Rajiv, Aman and Samantha emanate from the most recent e-survey sample (2014) in which the latter two cases represent newer destination choices for highly skilled South African migrants. The case studies are presented together with the discussion and the names of the informants are fictitious.

\section{The geography of highly skilled South African Indians}

\section{United Kingdom}

Neeta (42) is an ex-teacher and is married to Rahul (60), a dentist in London. They have been living in the UK for almost six years and have two children living with them and one child living in Australia. Both have families residing in South Africa and the UK, so they spend their time in Durban and London fulfilling family obligations and running a growing family business in manufacturing, which extends across national boundaries. Further, Neeta's entrepreneurial drive has led to retail projects that entail travelling between shops on the outskirts of London and in Johannesburg. Her transnational lifestyle and specifically gendered experiences of being a highly skilled professional with an aptitude for business, highlights how family (kin) and social networks (fictive kin) interact to provide the support systems necessary for the success of professional women migrants. Overseeing the family business in Durban while expanding business interests in the UK and South Africa means that her children and husband travel often enough to identify with being "on the move world citizens" who "have one leg here and the other, there". Straddling two international spaces with the prospect of Australia as another business option in the future, Neeta challenges the conventional notion of the highly skilled and brings a newer element of transnational entrepreneur into the equation. Unlike the highly skilled migrant who moves among the favoured high-income destinations before settling or returning to South Africa, Neeta's transnational existence suggests two countries (UK and South Africa) as the foundation upon which she envisages other countries as "satellite" destinations for future business interests. Neeta and Rahul remit money to their immediate families and belong to professional and cultural organizations in the UK but no longer to those in South Africa. However, their social life revolves primarily around the South African diaspora in London, accommodating visiting friends, family and business associates from South Africa and maintaining these connections in their own travelling to strengthen business rapport and linkages. Neeta associates Durban with her mother and extended family, holidays and religious practice while London is about her roles as wife, mother and 
business-woman. The two spaces share much overlap and are difficult to extricate from her perception of being both settled and mobile simultaneously. Her ongoing financial and technical support of the South African family business has contributed towards the well-being of family members and the empowerment of locals through the creation of employment. This indirect "payback to South Africa" is one of the less acknowledged contributions noted in migration literature and exposes the limitations in migration discourse on how migrants actually distribute personal time, expertise and capital towards varying configurations of local investment.

Literature on "ethnic entrepreneurs" (Bonacich, 1973; Aldrich and Waldinger, 1990; Kloosterman and Rath, 2003; Saxenian, 2006) refers to migrants and minority communities who are known to assist individuals to forge business opportunities between social groups through self-employment, entrepreneurship and small business. Neeta is a transnational ethnic entrepreneur as her kinship obligations (family business) and her international client base is predominantly South African Indian. Globalisation has enabled the South African Indian diasporic group to provide the social and cultural capital necessary for her business activities.

\section{Australia}

Kajal (48) is a specialist physician who is a partner in a medical conglomerate. Being unmarried with no children, she believes she has been able to embrace her transnational lifestyle far more easily. Her parents live in South Africa and her close relationship with her orphaned nieces has determined her "to-ing and fro-ing" mobility between countries. The medical practice consists of twenty specialists who spend between three to six months at a time in South Africa and Australia on a rotational basis. Family support and her religious beliefs underpin the support necessary for her to achieve and forge ahead as a woman in a scientific and male dominated medical career. Often referred to as a "global player" and part of a "jet-set elite" among the highly skilled, she revealed that her lifestyle was "physically and mentally draining" and that the travelling was highly romanticized by those who did not share the experience. The periods spent in Australia in particular, were intense and exhausting with no time to socialize or enjoy the country itself, despite having relatives living within proximity of the hospitals she networked with. It was only in South Africa that she could take the time to recharge before the next cycle. Kajal was the sole breadwinner and she supported her parents and nieces entirely. She owned the family property in South Africa and planned on purchasing an apartment together with her 
partners for company use during visits to Australia, indicating her interest and engagement in property investment locally and abroad.

\section{Canada}

Rajiv (35) is a physician/medical doctor (General Practitioner) who has been living in Canada for two years. He left South Africa for Canada because he believed that he could live and work in a qualitatively better social environment with far better resources and professional opportunities than in South Africa. His migration experience began as a teenager when two of his uncles left the country to work and eventually live in Canada. It is their experiences and support that shaped his ambition and his decision to emigrate. His exposure to their journey, advice and support system in Canada provided the social capital needed by highly skilled migrants to choose the best destination options. Rajiv would like to spend a year in Canada before heading to practice medicine in the United States. He does not wish to return to South Africa but expressed that: "Durban will always be home and South Africa is in my blood". His South African friends and colleagues in Canada share varying motivations for working in Canada and none planned on returning, except for family holidays. Rajiv thinks the primary reasons South African doctors chose Canada were professional opportunities, financial gain and a safer society (safer professional and social environments) in which to live and work. Also, the high quality of medical education and training received in South Africa makes South African doctors prime candidates in Canada. He remits money on a monthly basis to his parents and younger sister who is studying medicine in India. He related how she was not accepted to study medicine in Durban because of the quotas of Indian student numbers imposed on local medical schools which left her no option but to study abroad - a choice which his parents could not afford. He owned some property in South Africa including the family house and had recently purchased an apartment in India for his sibling. He did not contribute to any South African organizations, development projects or diaspora organizations. Rajiv was unmarried and was not planning on having a long-term relationship until he had decided where he would eventually settle. This factor, he said, would determine whether his future spouse would be a local or a South African woman. His only experience of being "Indian" in Canada was with his uncles and their families who came together to celebrate the major religious festivals such as Diwali.

Rajiv's profile is supported by local studies and public debate on medical professionals in Canada. A study conducted in 2005 investigating the 
reasons for doctor migration from South Africa (Bezuidenhout et al., 2009) indicates that financial reasons, poor working conditions and the high rate of crime and violence in the country were the main motivating factors for emigration of doctors. The HIV and AIDS situation in South Africa is also a major push factor for medically qualified professionals to leave the country. A media report entitled "South African diaspora, a study in apartheid" (6 January 2014) refers to a series of research papers of South Africans living in Canada, where a distinction is made between pre- and post-apartheid immigrants (Friesen, 2014). In this survey it was found that low levels of engagement, investment and interest in returning to South Africa, characterized those who arrived post 1994. The survey indicates that South Africans are an unusually well-educated and wealthy group of migrants with one in four earning more than \$200,000 annually, roughly the top 1\% in Canada, and more than $40 \%$ earning more than $\$ 100,000$, equivalent to the top $6 \%$ (Friesen, 2014). A partial explanation for such prosperity is the controversial recruitment of South African physicians to help address Canada's doctor shortage, making South Africa the leading source of foreign-trained doctors. In a recent newspaper article (27 February 2014), the National Health Minister expressed the government's frustration at retaining doctors and nurses in South Africa (Pakhathi, 2014). Updating members of Parliament's Health Portfolio Committee on the National Health Insurance (NHI) pilot projects, he warned that the roll-out of the NHI would not succeed if the shortage of doctors in South Africa was not addressed. Locally, the department was struggling to contract general practitioners for the NHI pilot projects. South Africa has one of the lowest doctor to patient ratio in the world and local medical schools produce an inadequate 1000 doctors per annum. The minister stated that: "Doctors, nurses and skilled people around the world move to greener pastures where they are better paid. If you meet the Canadians, they will tell you how many doctors they are losing to the US. Canadians say - if it were not for you guys in South Africa then we would be finished because all our doctors go to the USA. Our doctors will then move to replace those in Canada or move to Australia or England" (Pakhathi, 2014).

Also evident from the migrant voices of the destination countries (Canada, US, Australia and the UK) is the easy entry and assimilation of OECD policies that target highly skilled and educated migrants. Such policies range from providing special visas for the highly educated to citizenship laws, recognition of professional qualifications and provision of access to public services such as education and healthcare. The increase in demand 
for highly skilled workers in the US has been filled through permanent employer-based resident cards for individuals with advanced degrees in science and technology, temporary $\mathrm{H}-1 \mathrm{~B}$ visas for highly skilled workers and intra-company transfer (L1) visas. Australia, Canada and New Zealand award higher points for highly educated applicants for work permits and the European Union (EU) is considering a "blue card" which would grant highly skilled professionals selected through a points system unrestricted access to EU labour markets after an initial period in the host country (Migration and Remittances Factbook, 2011: 140).

The three case studies to follow provide snapshots of migrant experiences in some of the newer destination choices of highly skilled migrants, namely Dubai, Switzerland and South Korea.

\section{Dubai}

Cassim (36) works in the hospitality industry at executive management level. Having qualifications in commerce and business administration and experience in hotel management, he came to Dubai via a recruitment company after it had become difficult for him to find appropriate employment in South Africa. He felt stifled by the lack of local opportunities and instead of settling for employment which he was over-qualified for and being shortlisted at job interviews, only to be told he was not an affirmative action candidate. He chose to take the risk of working abroad and leaving his young family in South Africa. His wife and young child remained in South Africa and he travelled to visit them every six months. His wife, a former police officer was frustrated at being sidelined for promotion in the police-force on the basis of her colour. The prioritization of black (African) female staff in the ranks led to her eventual resignation. Cassim's financial contribution to the household trebled since he began working in Dubai and it became possible for her to care for their child on a full-time basis. Cassim would prefer his family to join him but was uncertain about his next career destination and the company had set their sights on another project in Bahrain. He expressed great appreciation for working in the UAE and had become accustomed to travelling and living away from home. The financial gain and professional work experience had enabled him to forge ahead with his career objectives and alleviate the financial constraints he experienced in South Africa. Being of Islamic background, he had easily integrated into the cultural ethos of Dubai and particularly enjoyed the cosmopolitan and crime-free society. When he had time to socialize, it was among his South African colleagues and friends as the South African diaspora in Dubai was well established. 
In a newspaper article entitled "Welcome to South Africa's $10^{\text {th }}$ province" (12 January 2008), it is estimated that more than 65,000 South Africans live in the UAE (Gerardy, 2008). In 2008 expatriates referred to Dubai as another South African province. Research has shown that South Africans opting for the UAE are highly skilled professionals: educated, cosmopolitan and mobile set. Fifty percent of South Africans moving to Dubai are graduates with a quarter having post-graduate qualifications. The top favoured sectors are construction, medicine, hospitality, management and education. The idea for most jobseekers is that Dubai is a tax-free gold pot of fabulous money-earning opportunities. The Homecoming Revolution, a South African based organization aimed at encouraging South African migrants to return home, observed that the community in the UAE was transient and that average stays were of a shorter duration than those in traditional destinations like London (UK) (Gerardy, 2008). The shorter duration of stay in Dubai is based on the fact that, unlike the UK before 2008, it is not possible to gain citizenship in the UAE.

Cassim's experience of poor employment opportunities, his wife's termination of employment based on Affirmative Action preferences and a higher earning potential of employment overseas, were the key motivations for his choice to leave South Africa. The aforementioned media reports affirm this trend, indicating the growing South African presence in destinations such as Dubai.

\section{Switzerland}

Samantha (30) is a brand manager for a multinational consumer goods company. She moved to Switzerland on a three-year company project and had one of two options for her career. She could either remain with the same company for three more years or join another multinational company which had recently head-hunted her, and move to another part of Europe. She migrated to Switzerland with her mother as her dependent and started an organic confectionery business in Switzerland which she marketed among South African expatriates and Swiss locals. She opened her first shop in 2013, which her mother manages. As the only child of a widowed mother, Samantha's "support system" travels between South Africa and Switzerland, while she traverses Europe in her business dealings. Her involvement in organic food is always outside work hours but her marketing of the product has been mainly in Switzerland. She owns property in Switzerland and South Africa and her mother (an ex-teacher) has bought an apartment in Durban to which she would like to eventually retire. She 
does not remit money to South Africa nor does she belong to any local or diaspora organisations.

Samantha has plans to market her food concept in the main South African cities, which her mother will oversee while Samantha travels in Europe on company business. Her visits to South Africa have become less frequent as her expertise required her to travel within the EU. She has no intention of returning to South Africa and has put relationships and marriage on the backburner until she "meets the right person". Samantha earns almost ten times more than her previous salary in South Africa and is content living in Switzerland for now because of its "efficiency, cleanliness, stress-free and crime-free environment". She observed that the social cleavages (particularly race) of South African society had migrated into the diaspora and that South Africans did not actively seek out other nationals for the sake of association. It seems that in the newer destination choices where the numbers are few and South Africans are geographically dispersed, diaspora members do not represent a united group.

\section{South Korea}

Aman (41) is a civil engineer by profession and works as a project manager on an engineering project for a South African company in Seoul. He is married, with three children, two of whom are residing in Korea and one who is living in South Africa. Since 2009, he has worked on projects in China and Uzbekistan before moving to Seoul, where he will remain until the completion of the project. He is not planning on returning to South Africa and hinted at moving to a new Asian project location in the future. Aman remits money to his immediate family in South Africa and continues to support personal investments, professional associations and local development projects (community based organizations) in South Africa. His professional qualifications, experience and post-graduate diplomas in engineering and business administration have made him a sought after engineering and project management expert. Aman's case study provides limited detail due to data being elicited from an e-survey. However, this should not detract from the significance of a transnational trajectory, a transnational family and the continuation of tradition by a highly skilled professional who continues to have a vested interest in local religious organizations which he supports on the basis of his cultural background. 


\section{Migration motivations}

The ten most significant migration motivations of the sample of 50 highly skilled South African Indian professionals (across the three samples) revealed that it was the lure of financial gain (earning in a stronger currency) that prompted migration, indicated by 40 of the 50 participants of the sample. Next in order of importance were: employment opportunities, 30 informants; crime and safety, 25 informants; and the Affirmative Action Policy with regard to employment, 20 informants. To follow, but of equal significance were: high levels of taxation, 15 informants; the high prevalence of HIV/Aids, 15 informants; professional development, 15 informants; and poor public services, 15 informants. Better working conditions, 10 informants and personal circumstances, 10 informants, followed closely behind. The table below illustrates the motivations for overseas migration and percentages of the highly skilled South African Indian sample, in order of importance.

Table 1. Motivations for the migration of highly skilled South African Indians

\begin{tabular}{lll}
\hline \multicolumn{2}{l}{ Motivations } & Percentage $\mathbf{( N = 5 0 )}$ \\
\hline 1. & Financial gain & $80 \%$ \\
\hline 2. & Employment opportunities & $60 \%$ \\
\hline 3. & Crime and safety & $50 \%$ \\
\hline 4. & Affirmative Action Policy & $40 \%$ \\
\hline 5. & High taxation & $30 \%$ \\
\hline 6. & HIV/Aids & $30 \%$ \\
\hline 7. & Professional development & $30 \%$ \\
\hline 8. & Poor public services & $30 \%$ \\
\hline 9. & Working conditions & $20 \%$ \\
\hline 10. & Personal circumstances & $20 \%$ \\
\hline
\end{tabular}

Remittance behaviour (Table 2) indicated that half of the sample sent money to immediate family in South Africa: 25 informants remitted frequently, ten informants remitted infrequently and five informants did not send any remittances. Half of the sample also owned property and had personal investments in the country. Only five participants contributed towards development initiatives, community organisations and alumni 
in South Africa. The low numbers reflected in diasporic activities and national development in the sample is supported by Crush and Chikanda's study (2012) of the disengagement of the South African medical diaspora. The study similarly indicates the low level of commitment of this group of South African professionals towards diasporic relations and addressing social and economic inequalities in South Africa.

Indian women in the sample predominantly supported their parents, medical expenses and daily expenses of the household (particularly where children remained in the care of the parents or family members), while Indian men contributed more towards household renovations, property and investments. However, the case studies of Neeta, Kajal and Samantha indicate that women were also investing in property, both locally and overseas.

Table 2. Remittance and investment behaviour of the sample

\begin{tabular}{lc}
\hline Remittance behaviour & Percentage $\mathbf{( N = 5 0 )}$ \\
\hline Remitted frequently & $50 \%$ \\
\hline Remitted infrequently & $20 \%$ \\
\hline Did not remit & $10 \%$ \\
\hline Investment behaviour & Percentage (N=50) \\
\hline Property and personal investments & $50 \%$ \\
\hline Development/community/alumni & $10 \%$ \\
\hline
\end{tabular}

Other findings of the highly skilled professionals revealed that nine participants or $18 \%$ of the sample had family living in the destination country which helped facilitate their adjustment there. This is further indicated in the case study of Rajiv in Canada whose migration experience began through the emigration of close kin. Moreover, ten participants or $20 \%$ of the migrants socialized among family and friends from the South African diaspora. The sample data also suggested that South Africans with stronger friendships and professional connections dominated in those destinations that had larger numbers of South Africans such as the UK, Canada and Dubai. 35 participants or $70 \%$ of the sample did not wish to return to South Africa and this is reiterated in the selected case studies. Comments from the e-questionnaire, e-survey and ethnographic study allude to financial gain, safety and security as key signifiers in the motivation for international migration. This is evident in Table 1 where financial opportunity and crime feature in the first three motivations for leaving South Africa. Twelve par- 
ticipants or $24 \%$ were unsure of their future migration plans, and only three participants or $6 \%$ indicated a definite return to reside in South Africa permanently.

The six selected case studies show the diversity of destination choices available to these migrants, their highly mobile and changeable lifestyle, their ability to draw on resources and social capital in several ways to reconfigure their lives as well as their unwillingness to return to South Africa. The women informants in particular had the additional roles of parent, spouse and care-giver which added further complexity to their social worlds and mobility. The emergence of ethnic entrepreneurs who initiate projects and fledgling businesses in addition to being highly skilled professionals, are benefitting both countries (of origin and destination) through the creation of employment, knowledge, skills transfer and financial investment. Contributions or "paying back" to South Africa should not be narrowly viewed in terms of remittances only as migrants engage in various ways with their country of origin. Although the sample size is relatively small, the data suggests that the transnational migration of highly skilled South African Indian professionals will continue for as long as South Africa does not actively engage with the diaspora with the intention of retaining its highly skilled professionals. The weak local currency, poor employment opportunities and crime in the country require urgent attention if the country wishes to sustain economic development goals and address the growing skills shortages.

\section{CONCLUSION}

Given that skills loss is being experienced at a rate that exceeds brain gain, brain circulation and the return migration of the highly skilled on the continent and in South Africa, much of the solution seems to point to the retention of professionals. This is a difficult task as South Africa cannot match the incomes and benefits offered internationally (particularly of the developed nations). The highly publicized outflow of public health sector personnel specifically, indicates that the loss can only be made up over many years even if the situation is at present being "contained". The entrenched fear of crime in the daily lives of South Africans extends to the diaspora. Regional studies among healthcare workers and other professionals indicate that violence and crime as a reason for international migration features among the key reasons for emigration, particularly in South Africa. The Affirmative Action Policy with regards to the employment of 
Black (particularly African) South Africans receiving preferential treatment has led to disillusionment and frustration among Indian and White professionals already struggling against the rising unemployment rate in the country. These factors also reflect in this study as the dominant motivations for leaving the country, and the discontent with professional development, inadequate resources and working conditions is also evident. Recent media reports indicate that the world economic crisis in 2008 has led to the return of economic migrants to South Africa. However, the impact of this has been ineffectual as it is reportedly the lower skilled migrants who have returned.

The alienation of the South African diaspora and the disinterest of the highly skilled in forming associations and connecting with each other, cited earlier in the paper, confirms that if South Africa is to benefit from the diaspora of highly skilled migrants, more effort is required to tap into this resource for knowledge transfer, the creation of trade networks and directing foreign investment back to South Africa. Perhaps this would in turn encourage more interest in migrants forging closer bonds amongst themselves overseas. Brain drain and brain gain theories are inadequate frameworks within which to embrace the complexities of changing processes, experiences and policies. Transnational migration theory provides a more embracing perspective of the variation and changeability experienced by relationships between migrants and non-migrants, home and host countries, and the nuanced ways in which highly skilled migrants invest in both.

The international migration of highly skilled professional South African Indians is not easily generalisable. The contributions of this ethnic group deserve further attention, particularly in the area of remittance behaviour on a national scale.

\section{REFERENCES}

African Economic Outlook (2014). Developing Technical and Vocational Skills in Africa, www.africaneconomicoutlook.org/theme/developing-technical-vocational-skills-inafrica (27 August 2014).

Aldrich, H. E. and Waldinger, R. (1990). Ethnicity and Entrepreneurship, Annual Review of Sociology, 16 (1): 111-135, doi: 10.1146/annurev.so.16.080190.000551.

Beck, U. (2008). Mobility and the cosmopolitan perspective, in: W. Canzler, V. Kaufmann and S. Kesselring (eds). Tracing Mobilities: Towards a Cosmopolitan Perspective. Aldershot: Ashgate, 25-35.

Beine, M., Docquier, F. and Rapoport, H. (2008). Brain drain and human capital formation in developing countries: winners and losers, Economic Journal, 118 (528): 631-652, doi: 10.1111/j.1468-0297.2008.02135.x. 
Bezuidenhout, M. M., Joubert, G., Hiemstra, L. A. and Struwig, M. C. (2009). Reasons for doctor migration from South Africa, South African Family Practice, 51 (3): 211-215, doi: 10.1080/20786204.2009.10873850.

Bonacich, E. (1973). A theory of middleman minorities, American Sociological Review, 38 (5): 583-594, doi: 10.2307/2094409.

Council of the European Union (2009). Council Directive 2009/50/EC of 25 May 2009 on the conditions of entry and residence of third-country nationals for the purposes of highly qualified employment, Official Journal of the European Union, L 155, 18. 6. 2009, 17-29.

Crush, J., Pendelton, W. and Tevera, D. S. (2005). Degrees of Uncertainty: Students and the Brain Drain in Southern Africa. Cape Town - Kingston: IDASA - Queen's University. (Migration Policy Series, no. 35). http://www.queensu.ca/samp/sampresources/ samppublications/ (10 June 2008).

Crush, J. and Chickanda, A. (2012). The Disengagement of the South African Medical Diaspora. Kingston: Queen's University (Migration Policy Series, no. 58), http://www.queensu. $\mathrm{ca} /$ samp/sampresources/samppublications/ (27 August 2014).

Docquier, F. and Marfouk A. (2007). International migration by education attainment, 1990-2000, in: C. Özden and M. Schiff (eds). International Migration, Remittances and the Brain Drain. Washington DC: World Bank - Palgrave Macmillan, 151-199.

Friesen, J. (2014). South African diaspora a study in apartheid, The Globe and Mail, 06 January 2014, http://www.theglobeandmail.com/news/world/south-african-diaspora-astudy-in-apartheid/article16201295/?page=all (27 August 2014).

Gerardy, J. (2008). Welcome to South Africa's 10 $10^{\text {th }}$ province, IOL News, 12 January 2008, http://www.iol.co.za/news/south-africa/welcome-to-south-africa-s-10thprovince-1.385547\#.VFNhlKJ3MgQ (27 August 2014).

Gould, B. (1988). Skilled international labour migration: an introduction, Geoforum, 19 (4): 381-385, doi: 10.1016/s0016-7185(88)80010-1.

Govender, D. and Sookrajh, R. (2013). Theorizing the lived experiences of Indian diasporic academic women: stoic arborescence or rupturing rhizomes?, Man in India, 93 (4): 557-575.

Iredale, R. (2001). The migration of professionals: theories and typologies, International Migration, 39 (5): 7-26, doi: 10.1111/1468-2435.00169.

Kew, J. (2014). South African skilled workers return on global economic weakness, Bloomberg, 14 January 2014, http://www.bloomberg.com/news/2014-01-14/southafrican-skilled-workers-return-on-global-economic-weakness.html (11 August 2014).

Kloosterman, R. and Rath, J. (2003). Immigrant Entrepreneurs in Advanced Economies: Venturing Abroad in the Age of Globalization. Oxford: Berg Publishers.

Levitt, P. and Glick Schiller, N. (2004). Conceptualizing Simultaneity: a Transnational Social Field Perspective on Society, International Migration Review, 38 (3): 1002-1039, doi: 10.1111/j.1747-7379.2004.tb00227.x.

Lowell, L. (2008). Chapter 2: Highly skilled migration, in: G. Appave and R. Cholewinski (eds). World Migration 2008: Managing Labour Mobility in the Evolving Global Economy. Geneva: International Organization for Migration, 51-76.

Manik, S. (2010). The migration of teachers from KwaZulu-Natal, South Africa to the United Kingdom: escaping adverse leadership and management, The Anthropologist, 25 (1-3): 109-120. 
Migration and Remittances Factbook: 2011 (2011). Washington D.C.: World Bank.

Mills, E., Kanters, N., Bansback, A., Hagopian, J., Nachega, M., Alberton, C., Au-Yeung, C., Mtambo, A., Bourgeault, S., Luboga, S., Hogg, R. and Ford, N. (2011). The financial cost of doctors emigrating from Sub-Saharan Africa: human capital analysis, British Medical Journal, 343 (3): 7031, doi: 10.1136/bmj.d7031.

Nathan, M. (2014). The wider economic impacts of high-skilled migrants: a survey of the literature for receiving countries, IZA Journal of Migration, 3 (4), doi: 10.1186/21939039-3-4.

Nedelcu, M. (2012). Migrants' new transnational habitus: rethinking migration through a cosmopolitan lens in the digital age, Journal of Ethnic and Migration Studies, 38 (9): 1339-1356, doi: 10.1080/1369183X.2012.698203.

Nyamvura, T. (2014). Tapping into the brain gain, South African Institute for Professional Accountants - SAIPA press release, 12 May 2014, http://www.saipa. co.za/pressreleases/356508/tapping-brain-gain (20 August 2014).

Oberoi, S. and Lin, V. (2006). Brain drain of doctors from Southern Africa: brain gain for Australia, Australian Health Review, 30 (1): 25-33.

Pakhathi, B. (2014). SA faces uphill battle to retain doctors, nurses, Business Day BD Live, 27 February 2014, http://www.bdlive.co.za/national/health (27 August 2014).

Pattundeen, G. (2007). Transnational lifestyles and transformation of gender relations: professional Indian women in Durban, KwaZulu-Natal, Anthropologist: Special issue, 2: 25-35.

Plaza, S. and Ratha, D. (2011). Harnessing Diaspora Resources for Africa, in: S. Plaza and D. Ratha (eds). Diaspora for Development in Africa. Washington D.C.: World Bank, $1-54$.

Ratha, D., Mohapatra S., Özden, C., Plaza, S., Shaw, W. and Shimeles, A. (2011). Leveraging Migration for Africa: Remittances, Skills and Investments. Washington D.C.: World Bank.

Saxenian, A. L. (2006). The New Argonauts: Regional Advantage in a Global Economy. Cambridge: Harvard University Press.

Singh, A. (2008). South African Indian migration in the twenty-first century: towards a theory of "triple identity", Asian Ethnicity, 9 (1): 5-16, doi:10.1080/14631360701803187.

Spadavecchia, C. (2013). Migration of women from Sub-Saharan Africa to Europe: the role of highly skilled women, Sociología y tecnociencia / Sociology and Technoscience, 3 (3): 96-116.

The Decent Work Agenda in Africa: 2007-2015. Eleventh African Regional Meeting, Addis Ababa, April 2007. Report of the Director-General (2007). Geneva: International Labour Office.

Waller, L. (2006). Migration of skills in South Africa: patterns, trends and challenges. [S.1.]: SAMP (Migration Policy Brief, no. 20), http://www.queensu.ca/samp/sampresources/ samppublications/ (10 June 2008). 


\title{
Visokokvalificirani stručnjaci u pokretu: međunarodna migracija južnoafričkih Indijaca
}

\section{Gerelene Jagganath}

\begin{abstract}
SAŽETAK
Rad se bavi migracijskim obrascima visokokvalificiranih južnoafričkih Indijaca od 2006. do danas. Etnografija visokokvalificiranih relativno je nova u antropologiji, pa pridonoseći novijem diskursu o migraciji i dijaspori, naglašava potrebu za nizom metodoloških pristupa koji bi potkrijepili globalnu pokretljivost ljudi, prirodu multilokalnog istraživanja i značenje »visoke kvalificiranosti« u različitim geografskim kontekstima. Rad je podijeljen na dva dijela: u prvome se definira visokokvalificiranog stručnjaka prema novijoj literaturi i teoriji o globalnoj migraciji, a u drugome se prikazuju studije slučaja visokokvalificiranih migranata na nekoliko međunarodnih odredišta naglašavajući i kontekstualizirajući njihova iskustva u inozemstvu.
\end{abstract}

KLJUČNE RIJEČI: visokokvalificirani, odljev mozgova, dobitak mozgova, transnacionalna migracija, južnoafrički Indijci 